\begin{tabular}{|l|l|l||}
\hline \multicolumn{2}{|c|}{ PublisherInfo } \\
\hline \hline PublisherName & $:$ & BioMed Central \\
\hline \hline PublisherLocation & $:$ & London \\
\hline \hline PublisherImprintName & $:$ & BioMed Central \\
\hline \hline
\end{tabular}

\title{
Breast Cancer News
}

\begin{tabular}{||l|l|l||}
\hline \multicolumn{2}{|c|}{ ArticleInfo } \\
\hline \hline ArticleID & $:$ & 3675 \\
\hline \hline ArticleDOI & $:$ & $10.1186 /$ bcr-2000-2-webreport0008 \\
\hline \hline ArticleCitationID & $:$ & 0008 \\
\hline \hline ArticleSequenceNumber & $:$ & 41 \\
\hline \hline ArticleCategory & $:$ & Web Report \\
\hline \hline ArticleFirstPage & $:$ & 1 \\
\hline \hline ArticleLastPage & $:$ & 2 \\
\hline \hline & & RegistrationDate : 2000-2-21 \\
\hline ArticleHistory & $:$ & OnlineDate $\quad$ 2000-2-21 \\
\hline \hline ArticleCopyright & $:$ & Current Science Ltd2000 \\
\hline \hline ArticleGrants & $:$ & \\
\hline \hline ArticleContext & $:$ & 1305822 \\
\hline \hline
\end{tabular}




\section{Overview}

The aim of the site is to 'Bring you the latest news on breast cancer detection and treatment since 1996'. The site is split into five sections: Newsroom; Articles; Treatment; Support; and Links. The Newsroom consists of breast cancer news, listed by date, from the last few years and includes links to abstracts and full text of articles from breast cancer journals, press releases and Reuters news articles. The Articles link allows the user to view the news by topic (from a choice of 32 including clinical trials, prevention and screening, and risk factors: genetics). The support and treatment sections list all the relevant organisations in each state within the USA. There is also an extensive links list.

\section{Content}

Although this is a large site, it is very easy to navigate. There is also a search facility that makes finding information simple.

\section{Other comments}

The news pages are updated every couple of days. It is hard to judge how regularly the site as a whole is updated.

\section{Evaluation}

As a database for breast cancer developments over the last few years this site is comprehensive. The news is arranged in such a way that you can view all the latest headlines and then look in more detail at the news items of greatest interest. This is a good site to begin looking for information - if you don't find what you are looking for here, you will undoubtedly find out where to look. The links are all listed under topic, making it easy to find other relevant sites. A nice feature is the email alerting service. This provides free e-mail notification of 'breaking breast cancer-related news, new article postings, and significant changes or new features' added to the site. 